\title{
The impact of economy on the fight against trafficking in human beings in Kosovo
}

Arjeta Shaqiri Latifi

PhD Cand. South- West University" Neofit Rilski” Blagoevgrad, Bulgaria

\section{Abstract}

This research is focused on the study of the phenomenon of trafficking in human beings and combating this denigrating phenomenon of society, through the development of the economic factor. The economic environment (factors; political, economic, social, technical-technological) and the development of Kosovo's economy are studied, as a development potential of standard of living, which affects the fight against trafficking in human beings in Kosovo. A special role in the study has the issue of employment, with a focus on the labor market (potential of supply and demand for work), employment opportunities, wages, and living standards, interpersonal relationships (employer-employee) as the dominant factor which affect the preservation of dignity, integrity and creating hope and perspective for a life in a healthy and sustainable society. Trafficking in human beings in Kosovo has become a major concern of Kosovar society which is developing in the form of modern slavery, through individual crime and organized crime, in order to create profitable favors for individuals or organized groups. The purpose of the research was to analyze the level of economic development in Kosovo, development trends, in order to have a clear picture of the causes and indicators that present the current economic and social situation in Kosovo, as well as the promising prospects for the younger generations. This paper presented the statistical data available from the relevant institutions, related to economic development, unemployment, living standard (poverty), etc. The thesis of this paper is: Does economic development have an impact on combating trafficking in human beings in Kosovo? For the work of this study are used the theories of various world authors, which have addressed the issue of economic development, employment, living standards and social welfare issues. This study aimed to assess the economic situation in Kosovo, economic development opportunities, employment and its consequences in combating trafficking in human beings in Kosovo. This study had identified the findings recommendations on economic factors who had a direct impact on combating trafficking in human beings and the social consequences that are reflected in society. 
Keywords: economic potentials, economic development, employment, wages, welfare, trafficking

\section{Introduction}

The Republic of Kosovo has 1,782,115 inhabitants and a land area of 10,887 km², while it borders Albania to the southwest, Montenegro to the northwest, Serbia to the northeast and Macedonia to the south (Statistics, n.d.).

Kosovo has the potential of a young workforce (active working age), where two thirds of it, at the same time, are potential of the labor market (have educational qualifications), while they can not establish employment relations, due to; a) low development of the economy (as well as of the economic structure with conjuncture which does not enable high employment (electricity branch as the dominant branch in the economy of Kosovo), b) low payment of labor, c) inappropriate education and qualifications, according to the requirements of the labor market, ie the economy, d) employment trends and development of a better life abroad, etc.

The employment market in Kosovo was disordered, especially after 1999, when the Republic of Serbia destroyed the Kosovo economy through the war against the Albanians in Kosovo and as a consequence the UNMIK international protectorate was placed Kosovo, which administered and governed the economy of Kosovo.

Thus, many jobs were closed and there was a lack of vacancies, which resulted in the tendency of the population to move towards developed countries, or to find different alternatives, to make money in legal forms and non-legal (informal).

Great potential of active labor force on the one hand (supply) and the demand for employment are not in balance, because the country's economic development plan was not harmonized with demographic flows (internal and external demand) and was not created a favorable infrastructure for economic development, focusing on the potentials of natural and human resources, to create sustainable development and economic stability.

Thus, the gap between the supply of jobs by employers and the demand for employment by employees under the conditions of competition lies in the qualitative and quantitative demands of employment in the labor market ${ }^{1}$.

Therefore, the development of the economy in Kosovo under the conditions of sociopolitical transition was accompanied by a high degree of informality in; a) implementation of existing laws and regulations, b) payment of taxes, b) employment, c) trade in goods, respectively services, making illegal business activities attractive.

\footnotetext{
${ }^{1}$ Based on the International Student Assessment Program from "PISA", Kosovo ranks third from the bottom.
} 
Such informal actions were done due to; a) poor functioning of the respective state bodies (due to lack of human capacity in certain positions), b) technical-technological shortcomings (information management system). c) incompleteness of the respective legal framework, d) business ambitions to get rich faster, e) favorable informal conditions for business during the functioning of the market, f) the need of employees to improve their standard of living, g) etc.

In this way, the informal economy was dominant throughout the territory of Kosovo, especially in the border areas, which were frequented by marginalized society groups (who do not enjoy social protection, legal, health, physical security, etc.).

Victims of informality in the economy were groups of marginalized society, who were stigmatized by being deprived of the right to remuneration according to work (payment of labor equivalent, respectively deserved salary), as well as being mistreated or enslaved.

As a consequence of the deregulation of the economy ${ }^{1}$, it can be marked as a tendency of a) improvement of the destroyed physical condition of the existing economic potentials, b) re-functioning of the lost markets, c) change of the structure of the economy with a more suitable conjuncture for the market, d) change of the concept of economic development (rapid transition from the concept of centralized economy, in the concept of free market economy), f) reorientation and re-education of the labor force for supply in the labor market (in Kosovo) and in western countries, etc.

This development process was accompanied by changes in the socio-economic situation in Kosovo, reflected in; a) the state of the population in the country through emigration, b) the housing structure of the population through migration from rural to urban areas ${ }^{2}$.

Therefore, Kosovo as a country in transition, with low political and economic stability, is constantly faced with demographic movements and social problems, which are present phenomena, due to; a) high unemployment rate, b) high informality rate, c) inadequate social policies, which as a consequence of these socio-economic problems develop the phenomenon of trafficking in human beings, as a profitable activity.

The phenomenon of trafficking in human beings is present in the Kosovar society, which mainly attacks stigmatized persons (with family problems who are victims, of traffickers) with a low standard of well-being.

\footnotetext{
${ }^{1}$ Deregulation refers to changes that improve regulatory quality to increase economic performance, cost-effectiveness, or the legal quality of relevant institutional rules and formalities. Its purpose is to improve the daily life of citizens in relations with employers, to reduce the degree of slavery, respectively to regulate business relations with the labor force, by deservingly financing human labor. 2 According to the Kosovo Agency of Statistics in April of 2011, 61\% of the population lives in rural areas.
} 
Prerequisite for economic development and raising the standard of living (for better social welfare), the economic environment plays an important role (with factors; political, economic, social, technical-technological).

Advancing the economic environment, which includes political, economic, social and technical-technological factors, facilitates all spheres of action such as; a) rule of law (prosecutor, legislation, judiciary) b) free market economy (in investment, competitive industry, in all economic sectors, in revitalization of enterprises, c) employment (Govenment, 2016).

In Kosovo there has been a lack of satisfactory investment in the economy (low level of direct investment) as well as political instability (Kosovo has not yet managed to develop the necessary steps for integration in the regional and European market ${ }^{1}$ ), so it was faced with low economic development ${ }^{2}$.

Political difficulties make Kosovo's economy less competitive in the market, as it creates restrictions on equal participation with regional countries in the market.

As a result of this low state of economic development, there is dissatisfaction of the young population which is oriented to be better realized in the employment markets of European countries.

Thus, implementation of inadequate development policies in Kosovo has created an unfavorable economic environment and not so suitable, so that the economy of Kosovo is characterized with a fragile stability.

As a consequence of the low economic development, or the imbalance between the supply and demand of the labor force in the labor market, it leads to encouragement of traffickers for development of the informal market, respectively for development of slavery (which aims to exploit the most vital part of society for the purposes of trafficking through; prostitution, forced labor, performing hard labor, begging, organ trafficking, etc.).

Therefore, traffickers take advantage of the poor economic situation of job seekers, luring victims of trafficking (human beings) for a better welfare for the purpose of material gain.

\footnotetext{
1 Kosovo needs sustainable policies, which focus on quality economic development and employment plans and objectives.

${ }^{2}$ According to the Central Bank of Kosovo, the rate of economic development of Kosovo is low and ranks among the countries with the lowest rate of economic development in the region which has an annual trade deficit (reaching the figure of over 3 billion euros) resulting in discrepancy between the value of exports and imports.
} 


\section{Methodology}

This study, with a focus on "the impact of the economy in combating trafficking in human beings in Kosovo society", the factors were defined, which are determinants of the impact on low economic development.

As key factors are elaborated; a) Production, b) Consumption c) Financial revenues, d) Investments, e) State budget expenditures, f) Exports - Imports, g) Employment.

To study the movement of indicators, which measure; a) Economic development and b) Welfare standard, I was served with secondary data, provided by the competent institutions of Kosovo.

In order to process the relevant indicators of this paper and to make the respective scientific analysis, the following methods have been used: quantitative, qualitative, deductive, historical and comparative.

Using the mentioned methods, it has been proven which economic factors directly affect economic development, employment and living standards.

At the same time, the effects of economic factors on the development of the fight against trafficking in human beings in Kosovo, social stability and the prevention of negative phenomena in society have been studied.

Theoretical treatment of economic development

The process of economic development has been studied by many economists, who have made various theoretical descriptions related to; a) factors, b) principles, c) policies, d) methods, e) instruments-mechanisms, f) models, g) ideological philosophies, etc.

Based on the different theoretical treatments on the process of economic development by different scientists ${ }^{1}$ and theorists, there have been given different evaluations and orientations for the organization of economic concepts.

Based on these economic principles, economic policies have been developed which have influenced the decision-making for economic development and the rational behaviors of the population (CFI, n.d.).

1 1)The classics of political economy (Adam Smith- health theory; Paradox of value; David Ricardo, Marshall, Pigou, Cassels, Walras- welfare theory, Taussig, Knight- Classical theory of interest (real theory of interst, John Stuart Mill.), 2) Maltusianet (Thomas Robert Malthus- Theories on human population), 3) (Karl Marx- Theory on work aand value), 4) Neoclassical Economists (Alfred Marshall- T Marginal utility theory), 5) Keynesian economists (J.M.Keynes- The General Theory of Employment, Interest and Money; Investment multiplier; Marshall, Pigou, Cannan, Robertson, J.M. Keynes- The cash balance approach (Cambridge version), 6) Monetarist Economists - Chicago School Economists (Milton Friedman- Wealth theory of demand for money; Permanent income hypothesis; Ben Bernanke, 7) Economists of other schools (include the Austrian School, the Freiburg School, the School of Lausanne, post-Keynesian economics and the Stockholm school, etc.) 
The focus of these theorists was on the differentiation of ideas on how the economy works under the conditions of different class systems.

It must be noted that all economic theories were preoccupied with the functioning of the market (supply, demand), because goods and services are exchanged in the market.

Thus the essence of all economic theories lay in the ratio of the use of capital (goodsmoney) to labor (employer-employee relations) and creation of value.

So these theories have given general explanations (through independent variables and dependent variables) on; a) capital (investments), b) production, c) employment, d) consumption, e) exchange, f) added value, respectively national income (GDP) as elements of the economic system, showing their impact in determining economic development of a country.

By presenting these economic variables as elements of economic development, it has been ascertained that from those variables (productive forces) and the relations between them (relations in production) depend on; a) the level of economic development (national income), b) the level of living standard (consumption), c) the rate of employment, d) inflation, e) state expenditures, etc., which at the same time determine the level of economic stability of a place, etc.

Thus, the fluctuations of the stability of the economic system depend on; a) the constituent components of the economic system, b) the way of governing, c) the degree of elasticity of the economic system, d) the internal and external political influences, e) the technical-technological influences, etc.

The purpose of these theories was to lead the country towards prosperity, orienting public money in the fairest way possible, which will generate development, employment, improvement of living standards, income, stability, freedom and social security (CFI, n.d.).

Thus, from the elaborated ideas and theories, the development factors, labor needs and material needs (Ritzer, 2008) have been studied, which are regulated through the application of defined economic concepts (close connection of man with nature, man with capital, man with man and the purpose ( regulation of class interests).

These theories have been supported and opposed by various theorists, who have tried through philosophical concepts to distinguish or differentiate the usefulness of the use of one or the other theory, making the necessary rational comparisons (Ritzer, 2008).

As a conclusion of the review of the theoretical treatment of economic development, it can be concluded that all the theories have been focused mainly on the treatment of social classes and added value (Ritzer, 2008). 


\section{Analysis of economic development in Kosovo}

Kosovo has economic potentials, which are concentrated in the main branches of the economy; a) productive branches of the economy, b) service branches of the economy, c) small economy and handicraft.

The productive branches of the economy include: 1) agriculture (orchards, vegetables, plowing, sheepbreeding, stockbreeding poultry, beekeeping, fisheries);2) electricity (coal mining industry, energy production, energy distribution); 3) agricultural products of processing industry; 4) forestry; 5) wood processing industry; 6) mining; 7) metal processing industry; 8) textile processing industry; 9) construction industry and haberdashery, galanteria etc.

The service branches of the economy include: 1) trade; 2) hotel businesses; 3) tourism, 4) health, 5) education, 6) media arts, 7) information, 8) construction, 9) traffic (air, road, rail), 10) telecommunications (telephony, internet), etc.

The small economy and crafts include 1) services (auto mechanics, electrical, electronics, etc.), 2) handicrafts (embroidery, knitting, sewing, filigree, woodcarving, metalprocessing, etc.), 3) professional services (advocacy, expertise, consulting, etc.),

So, Kosovo is a country with a low level of development economy (GDP) ${ }^{1}$, compared to countries in the region, because until 1999 it was a country with the status of Autonomous Province, as a constituent element of the Socialist Federal Republic of Yugoslavia, while with the dissolution SFRY in 1999 and after the war between Kosovo Albanians against the police and military forces of the RS of Serbia, the UN2 protectorate was established in Kosovo (based on UN Resolution 1244) with the name UNMIK, which had the competence of administration and governance with the economy of Kosovo. Thus, since 1999, Kosovo is in the phase of transition (transition from the concept of centralized economy to the concept of free market economy).

After the destruction of Kosovo's economy by the RS (Republic of Serbia) government of Serbia during the 1999 war, as well as after the restructuring of Kosovo's economy by UNMIK, the creation of the basis for economic development began, by: 1) transformation of public property through the privatization process, 2) organization of the economy in the private sector and its empowerment. 


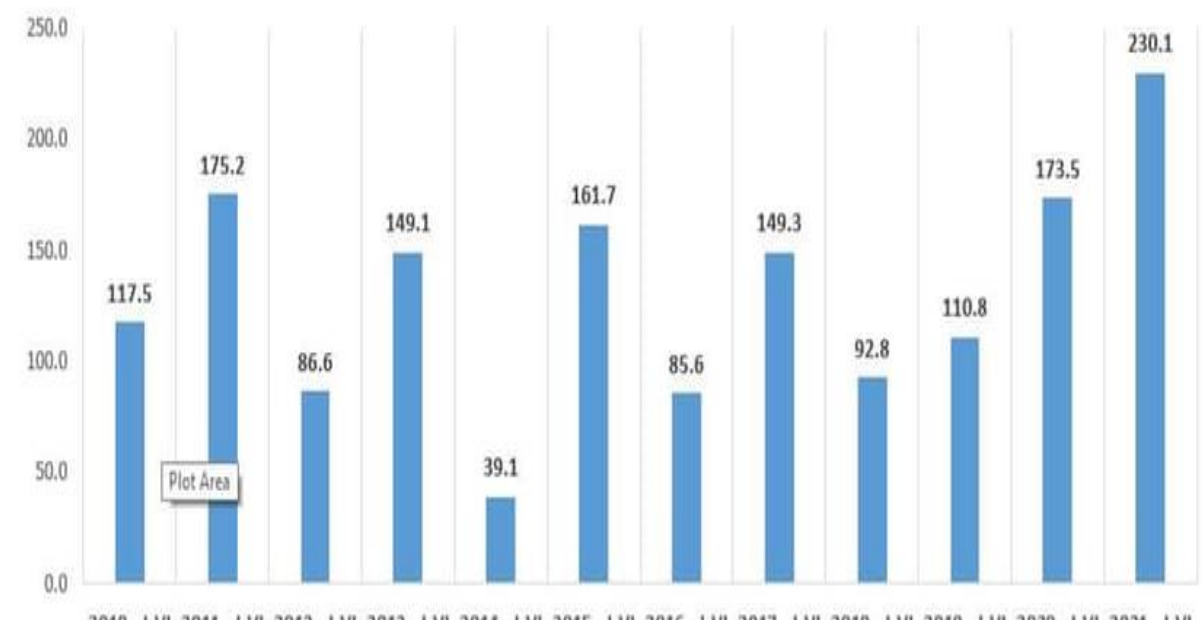

Fig. Nr.1 Situation of Foreign Direct Investment in Kosovo (FDI) during the period 2010-2021 (in the first six months of each year), (Source: https:// www. monitor al / per-gjashte-muaj-mbi-230-milion-euro-investime-te-huaja-ne-kosove)

The annual average of FDI (Foreign Direct Investment) in Kosovo during the period 2010-2021 was 130,941,666 Euros per year.

Viewed by sectors, FDI in Kosovo has invested in the following sectors: financial services, manufacturing, real estate, transport and telecommunications, electricity, mining, construction, manufacturing, sanitation, consulting and research operations, agriculture, commercial services and others.

Economic activities

Agriculture, hunting, forestry and

fishing

Mining and Manufacturing industry

Wholesale and retail trade
Gross Product Participation by activities

$\begin{array}{lllll}2014 & 2015 & 2016 & 2017 & 2018\end{array}$

$11,90 \quad 10,30 \quad 10,50 \quad 9,10 \quad 7,20$

$12,40 \quad 12,80 \quad 13,30 \quad 12,12 \quad 13,5$

$12,40 \quad 12,30 \quad 12,30 \quad 12,50 \quad 13,0$ 


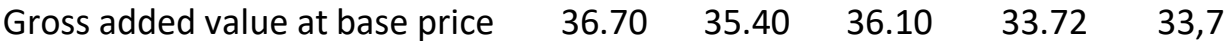

Fig. Nr. 2. Structure of Gross Domestic Product by economic sectors during the period 2014-2018 (Source: Statistical Yearbook of the Republic of Kosovo 2020) ${ }^{1}$.

According to the data of the Kosovo Agency of Statistics, Gross Domestic Product per capita (GDP per capita) during the period 2000-2019 had increased from $\$ 1,500.00$ USD / capita in 2019 to 4,000.00 \$ USD / capita, which is the main indicator and most important macroeconomic in the System of National Accounts ${ }^{2}$.

Thus, national income per capita, or GDP per capita, had increased from 1,500.00 \$ USD in 2019 to $4,000.00$ \$USD.

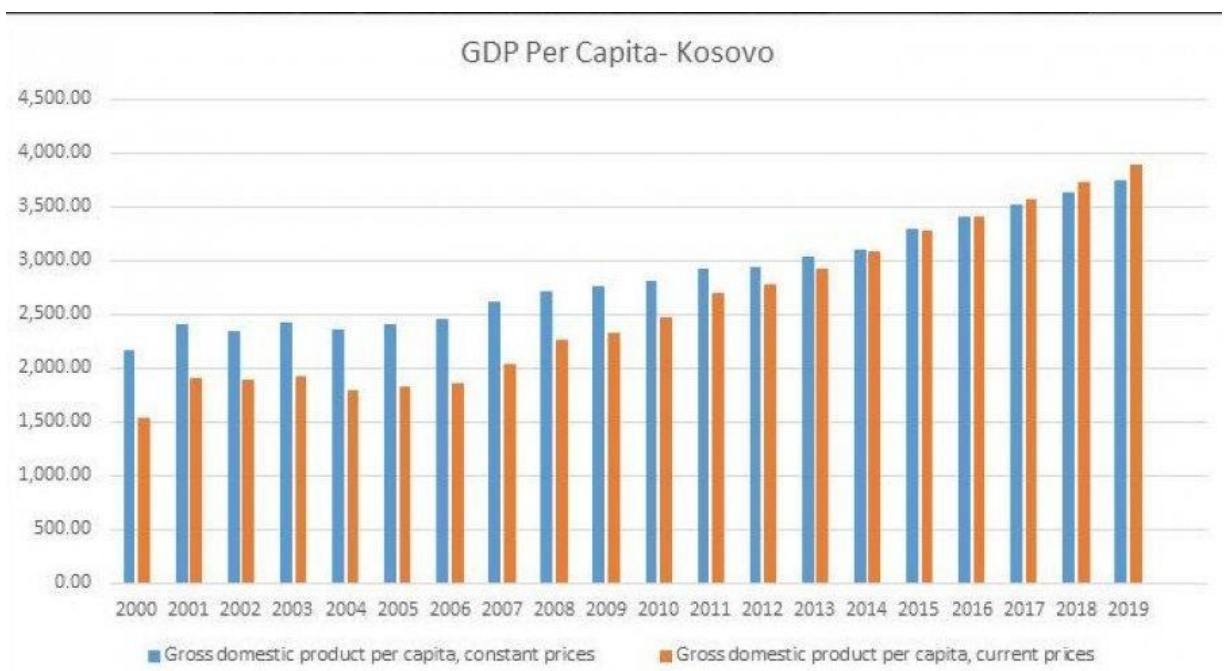

Fig.Nr.3. GDP per capita at constant and current prices in Kosovo during the period 2000-2019 (source: https://www.google.com/search

So, after 1999, the economy of Kosovo has begun to recover, to increase the degree of competitiveness in the domestic market and in the foreign market, based on; a) human capacities (low level of education), b) financial capital (high interest rates on loans), c) consumer demand (living standard), d) technical-technological potential and e) organizational capacities ${ }^{3}$.

\footnotetext{
1 Kosovo Agency of Statistics.

${ }^{2} \mathrm{GDP}$ represents the value of market prices of all material goods and the value of services produced domestically in the period of one year, respectively is the final result of the value of production (in all activities of resident production units), deducted from value of consumption, government expenditures, investments, difference between exports and imports.

(infoplease.com/business/economy/gdp-and-players-three-all-together-now-c-i-g)

3 The average age according to the Kosovo Agency of Statistics is 30.2 years.
} 


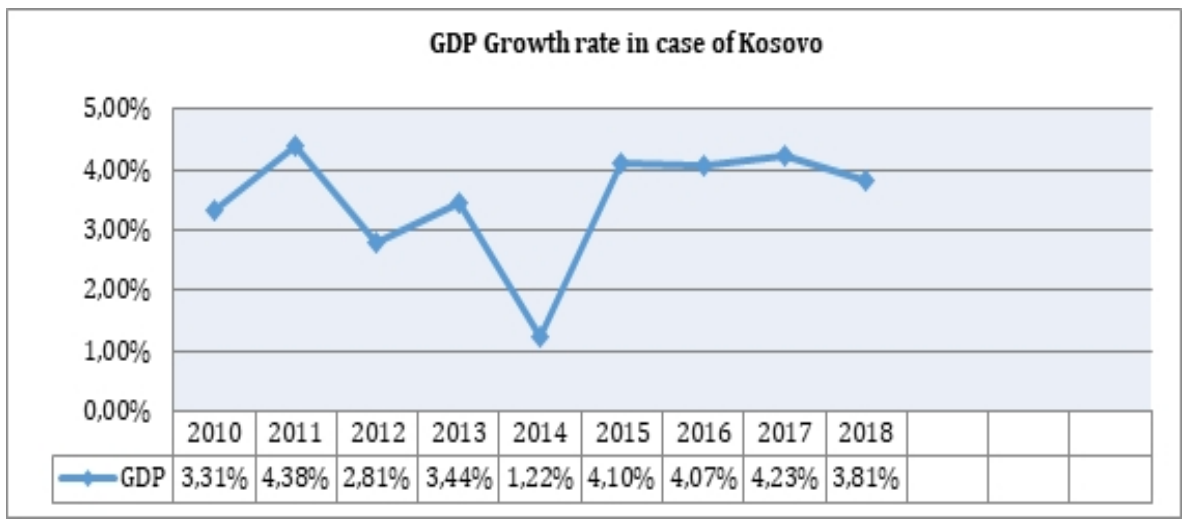

Fig. Nr.4. GDP growth rate in Kosovo during the period 2010-2018 (source: https://www.google.com/search)

Based on the available economic potentials as well as the used capacities of the local economy, Kosovo has realized an average GDP growth of 3.485\% during the years 2010 to 2018.

$\begin{array}{lcccc}\text { Key financial figures } & & & & \\ \text { EUR } & 2019 & 2020 & \mathbf{2 0 2 1} & 2022 \\ \text { Real GDP (\% yoy) } & 4.8 \% & (2.7) \% & 6.1 \% & 5.5 \% \\ \text { CPI Inflation (avg, \% yoy) } & 2.70 & 0.20 & 1.70 & 1.90 \\ \text { Unemployment (avg, \%) } & 25.7 & 24.5 & 24.0 & 23.5 \\ \text { Budget Balance (\% of GDP) } & (2.6) & (7.1) & (5.6) & (3.9) \\ \text { Public Debt (\% of GDP) } & 17.0 & 22.1 & 24.6 & 26.1 \\ \text { Current Account Balance (\% of GDP) } & (5.7) & (7.0) & (5.5) & (4.7) \\ \text { Nominal GDP (EUR bn) } & 7.1 & 6.9 & 7.3 & 7.9 \\ \text { GDP per Capita (EUR) } & 3.959 .4 & 3.896 .4 & 4.180 .0 & 4.529 .4 \\ \text { Private Consumption (\% yoy) } & 6.1 & 5.4 & 4.9 & 4.8 \\ \text { Government Consumption (\% yoy) } & 8.9 & 9.6 & 22.6 & 22.3 \\ \text { Exports of Goods and Services (\% yoy) } & 6.7 & (29.0) & 13.4 & 13.2 \\ \text { Imports of Goods and Services (\% yoy) } & 4.2 & (8.3) & 17.7 & 18.4\end{array}$

Fig. Nr.5. Macroeconomic variables forecast for the period 2019-2022 (Source: Raiffeisen Bank- Kosovo) 
According to the forecast of Reiffeisen Bank, the average growth of \% of GDP in Kosovo for the years $2019-2022$ is projected to be $4.77 \%$ or nominal GDP is projected to increase from 7.1 Bin Euro in 22019 to 7.9 Bin Euro in 2022, while the rate of The increase in inflation is forecasted by an average increase of $1.625 \%$, while the unemployment rate is projected to increase on average to $24.425 \%$.

As a result of the low economic level, Kosovo is constantly experiencing economic instability, which manifests itself through; a) high unemployment rate $(24.6 \%$ of the active working population is unemployed), b) high employment informality rate, c) high poverty rate $(29.7 \%$ of the population live within the borders of poverty, while $10.2 \%$ live in extreme poverty).

Based on this situation of the level of economic development, it turns out that the level of quality welfare in Kosovo is low.

Referring to these conditions of economic development, in particular the potential of the active power of workers for work, it turns out that two thirds of the population is of working age (15-64 years, respectively $60 \%$ of the population are of working age), but the current economy cannot absorb this human potential, because the employment rate in Kosovo is one of the lowest in the region.

Thus, the most favorable way for Kosovar youth to get a job, as well as to create prospects and make a better life, is to immigrate to western countries.

In the current conditions, in which is the level of economic development in Kosovo which is unfavorable for the employment of young people due to; a) informality in employment (is at a high level, especially among young people who have a low level of education ) (Group, 2019), b) minimum wage which is the lowest in the region (currently it is, for employees up to 35 years old is 130 euros, while for employees over 35 years old is 170 euros), c) nepotism in employment, especially in public institutions (influenced by the dominance of political parties in power, kinship ties, ties of interest groups, etc.), d) greed for realization of higher personal income in jobs in Western countries, d) poor functioning of trade unions, f) ineffective functioning of the labor inspectorate, g) discrimination of various forms in the employment process (gender discrimination, class discrimination, etc.)

In order to regulate the employment environment in Kosovo, it is necessary to change; a) approach to integration policies, b) approach to development policies (affecting the factors that hinder the development of the economic environment which enables economic growth, improvement of living standards), c) integration of all relevant factors, which in a way commit to improving and advancing economic stability in Kosovo (Govenment, 2016), by generating jobs and reducing unemployment (reducing poverty and raising living standards) (President, 2020). 


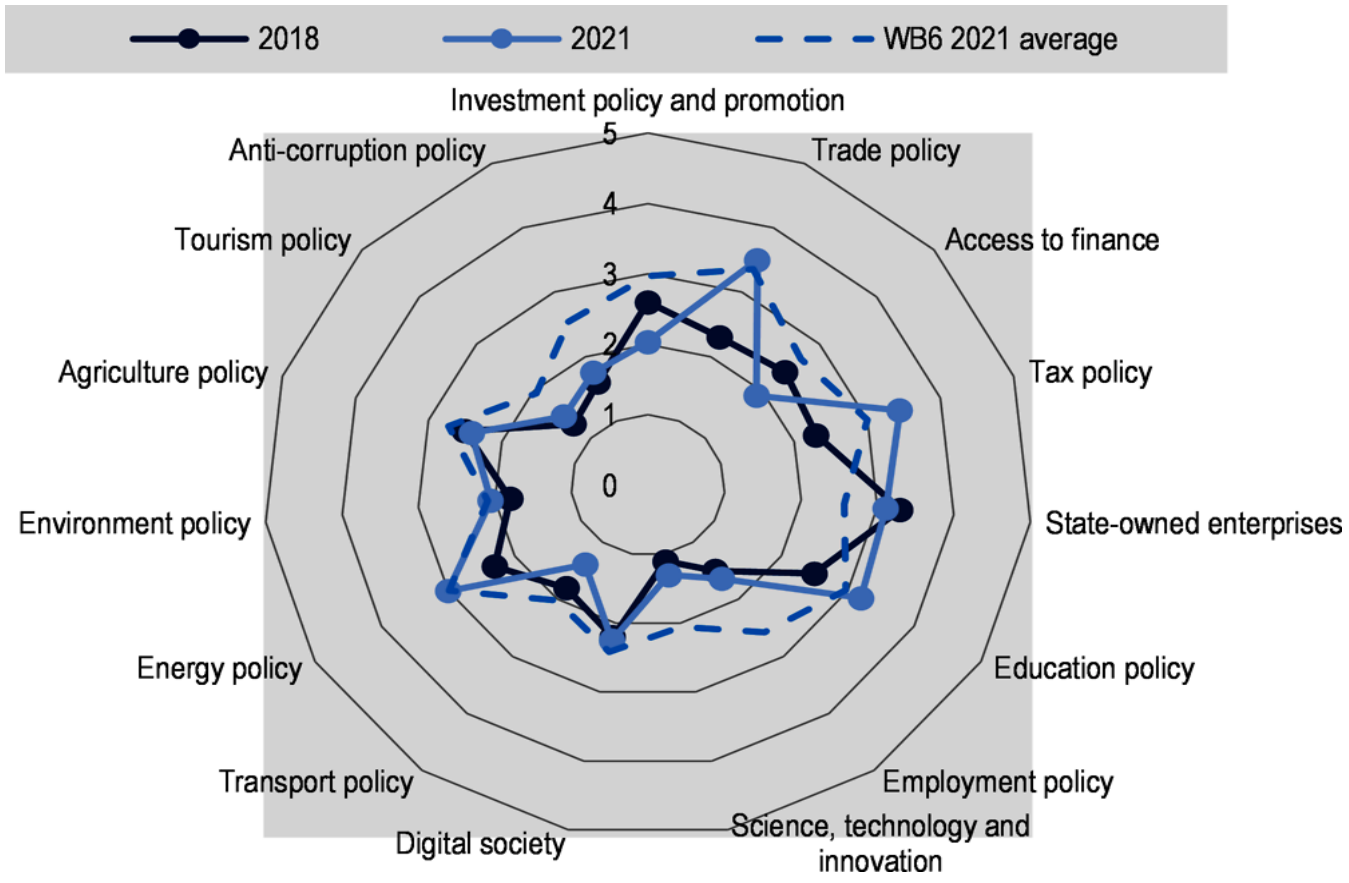

Fig. Nr.6. Impact of sectoral policies on economic development during the period 2018-2021 (Source; World Bank)

Based on the development policies of the economy during the period 2018-2021, it can be seen that the trade sector has had the greatest strengthening compared to other economic branches in Kosovo, followed by the energy, education and agriculture sectors, while the transport sector and digital economy remained in the same situation. On the other hand, there was a decline in the tourism, science and innovation sector, which were accompanied by a low increase in the employment rate or a low decrease in the unemployment rate.

Summary table of labour market indicators estimated based on the Quarterly Labour Force Survey, Q.4/17-Q.2/21

$\begin{array}{lllll}\text { Q.4. } & \text { Q.4. } & \text { Q.4. } & \text { Q4.2020 } & \text { Q2.2021 } \\ 2017 & 2018 & 2019 & & \end{array}$

$\mathrm{Nr}$ of active people for $1,216,59$ $1,236,62$ $1,274,85$ $1,231,45$ $1,238,04$ employment 15 years old and 9 4 7 2 6 over 


\begin{tabular}{|c|c|c|c|c|c|}
\hline \multirow[t]{2}{*}{$15-64$ years } & $1,167,78$ & $1,184,41$ & $1,210,61$ & $1,172,98$ & $1,171,86$ \\
\hline & 5 & 3 & 5 & 8 & 8 \\
\hline $15-29$ years & 227,414 & 283,679 & 276,984 & 264,300 & 267,275 \\
\hline $30-64$ years & 940,371 & 900,734 & 933,631 & 908,688 & 904,594 \\
\hline $\begin{array}{l}\text { Unemployed } 15 \text { years old and } \\
\text { over }\end{array}$ & 187,789 & 172,792 & 160,030 & 165,485 & 161,927 \\
\hline $15-64$ years & 184,596 & 172,465 & 159,174 & 164,733 & 161,101 \\
\hline $15-29$ years & 74,255 & 81,327 & 75,203 & 73,195 & 66,281 \\
\hline $30-64$ years & 110,341 & 91,138 & 83,971 & 91,537 & 94,820 \\
\hline Inactive 15 years old and over & 971,839 & 953,964 & 934,113 & 970,167 & 962,402 \\
\hline $15-64$ years & 652,768 & 617,340 & 595,998 & 609,349 & 597875 \\
\hline $15-29$ years & 349,304 & 330,835 & 329,364 & 323,870 & 309,504 \\
\hline $30-64$ years & 303,465 & 286,505 & 266,633 & 285,479 & 288,372 \\
\hline Labour Force 15 years old & $1,404,38$ & $1,409,41$ & $1,434,88$ & $1,396,93$ & $1,399,97$ \\
\hline and over & 8 & 6 & 7 & 7 & 3 \\
\hline $15-64$ years & $1,352,38$ & $1,356,87$ & $1,369,78$ & $1,337,72$ & $1,332,96$ \\
\hline & 1 & 8 & 9 & 1 & 9 \\
\hline $15-29$ years & 301,669 & 365,006 & 352,188 & 337,495 & 333,555 \\
\hline 30-64 years & $\begin{array}{l}1,050,71 \\
2\end{array}$ & 991,872 & $\begin{array}{l}1,017,60 \\
2\end{array}$ & $\begin{array}{l}1,000,22 \\
5\end{array}$ & 999,413 \\
\hline
\end{tabular}

Fig. Nr 7. Summary of labor market indicators estimated according to the Quarterly Labor Force Survey, Q4 2017 - Q2 2021 (Source: Kosovo Agency of Statistics)

According to the statistics of the Kosovo Agency of Statistics (KAS), it results that during the period 2017 (Quartal 4) The number of unemployed was 187,789 unemployed, while in 2021 (Quartal 2) The number of unemployed has decreased to 161,927 unemployed persons, which means that on average in Kosovo 5,172 workers are employed within a year. 


\section{Factors influencing trafficking in human beings}

Several factors influence the development of the phenomenon of trafficking in human beings ${ }^{1}$, which are as follows:

\section{1) Economic factors:}

a) The level of Gross Domestic Product, or GDP (the level of national financial revenues, in particular, the level of GDP per capita,

b) Structure of the economy (branches of the economy that affect employment,

2) Political factors:

a) state policies (degree of operation of the rule of law),

b) security in all areas of social stability

3) Sacial factors:

a) Culture, or tradition of the population,

b) The influence of countries in the region,

c) Information, respectively social networks, etc.

\subsection{Economic factors}

a) The level of Gross Domestic Product, or GDP (the height of national financial revenues), in particular, the height of GDP per capita, directly affects the determination of the living standard of the country's population.

Thus, it is more important for the population to have financial income that covers the expenses of the consumer basket and covers other expenses for life.

Under the situation, when the population of the country can not cover the needed and necessary expenses for living, it is forced to look for other alternatives to obtain other financial income, in order to meet its living needs.

Thus, unemployment and low standard of living (poverty), create preconditions for incitement to delinquency, respectively for the victimization of the materially endangered population.

\footnotetext{
1The phenomenon of trafficking in human beings refers to the process of; "recruitment, transportation, transfer, shelter or reception of persons, through the threat or use of force, or other forms of coercion, kidnapping, deception, fraud, abuse of power, or a position of vulnerability, respectively giving or receiving payments or benefits to obtain the consent of one person, having control over another person, for exploitation purposes. Exploitation includes, to a minimum, the exploitation of others for prostitution or other forms of sexual exploitation, forced labor or services, slavery or practices similar to slavery, yoke or removal of organ"
} 
Therefore, the efforts of the Government of Kosovo are focused on regulating of a favorable environment for economic development, in order for the economy of Kosovo to become as sustainable as possible, increasing the rate of; GDP, in particular GDP per capita (investments in the economy, production of local products that gradually replace imported products), employment, raising living standards (Government, 2017), etc.

b) Structure of the economy (branches of the economy that affect employment)

Among the economic branches which have priority in economic development are infrastructural activities; 1) Energy, 2) Communication infrastructure 3) Drinking water and sewerage network infrastructure, etc., which absorb high levels of investment (these investments are directly reflected in the promotion of economic development, in the creation of financial income), while enabling low employment rates.

On the other hand, some other branches of economic development enable investments in which employment is higher, but at the same time informality in employment ${ }^{1}$.

Informality in employment, in most cases is presented as a conditional factor of trafficking in human beings.

According to the Kosovo Center for Gender Studies in Kosovo, informal and formal businesses in which sexual exploitation takes place in Kosovo in various professions, such as masseurs and dancers. (there are 141 massages in Prishtina), while according to the Office for Protection and Assistance to Victims in Kosovo, it can be seen that within the period of 18 years, 20,659 cases have been assisted, of which 16,615 cases of domestic violence, while 14,550 cases were other forms of delinquency among women in Kosovo.

Thus, raising the rate of economic development in Kosovo, combating informality (damages, dignity, integrity, state financial revenues, and increasing the rate of crime), increasing the standard of living enable the development of the fight to prevent trafficking in human beings.

\section{Political factors}

a) State policies (degree of functioning of the rule of law

\footnotetext{
${ }^{1}$ Hoping for a better life with prospects, a stable salary, a better standard of living young people fall prey to traffickers
} 
In the absence of political stability in the country, elections are organized for representatives of the people in the government and executive bodies of the state. The representatives of political parties, especially the candidates running for these positions, make public and secret promises for employment, manipulating especially persons belonging to the poor (being promised positions in power, or jobs), who exploit them to achieve political goals.

Also, civil unrest organized by the affected or dissatisfied with the government affects the exploitation of people in need to express dissatisfaction with the actions of the existing government, which some of them commit delinquent actions, which are punishable by law and in such a way actors who break the law are not punished, they are forced to leave the country, especially under conditions when Kosovo has not been granted visa liberalization to European Union countries. In this manner they fall into the hands of the traffickers.

It has been recognized that when the "rule of law" does not work, then organized crime develops which is generated by persons who are positioned in influential positions in various security sectors, or the judiciary. This form of crime includes delinquents who are in the delinquency registers in state bodies, as well as persons in need.

Thus, trafficking in human beings constitutes a violation of human dignity and fundamental freedoms and is a serious violation of human rights, which every state has an obligation to respect, fulfill and protect the Universal Charter for the Protection of Fundamental Human Rights.

If a state that fails to meet these obligations can be held liable for a violation of the European Convention for the Protection of Human Rights and Fundamental Freedoms (ECPHRFF) ${ }^{1}$.

The Criminal Code of Kosovo adopted in 2012 penalises trafficking in human beings ${ }^{2}$. Also, in 2013 entered into force the comprehensive law against Trafficking (Law No. 04 / L-2018), "Law on Prevention and Combating Trafficking in Human Beings and Protection of Victims of Trafficking"3.

\footnotetext{
1 EGMATHM, Expert Group on Measures against Trafficking in Human Beings. Report on the compliance of Kosovo * with the standards of the Council of Europe Convention on Action against Trafficking in Human Beings. Approved on December 22, 2015 Published on April 12, 2016 Prishtina.

2 Article 172 (concealment of identification documents of victims of slavery or trafficking in human beings),

Article 169 (slavery, conditions similar to slavery and forced labor)

3 The law defines the authorities involved in the fight against trafficking in human beings and their responsibilities, the competencies of the National Anti-Trafficking Coordinator, as well as the role of the non-governmental sector

http://www.ror-rks.net/repository/docs/2016_03_16_155340_Ligji-per-parandalimin-dhe-luftimin-etrafikimit-me-njerez.pdf
} 
In addition, the Council of Europe Convention ${ }^{1}$ against Trafficking in Human Beings also defines trafficking as an act which is a violation of human rights and a violation of the dignity and integrity of human beings. The convention aims to prevent trafficking, protect victims and prosecute traffickers. This Convention covers all forms of trafficking, both national and international2.

This Convention on Action against Trafficking in Human Beings requires each state to have a comprehensive framework for the prevention of trafficked persons, protection of victims and effective investigation into the prosecution of traffickers ${ }^{3}$.

b) Security in all areas of social stability,

(Property security, individual security, comfort, social stability)

Property security in Kosovo is violated in cases when property owners ${ }^{4}$ are threatened by abusers who are in power and persons supported by them, so under these conditions, the owners are threatened, ie it is impossible to use their property. The threatened owners are forced to leave their place of residence and, at the same time, become prey to traffickers for trafficking (the case of Roma and Ashkali displaced from their property).

In absence of visa liberalization for Kosovo by the European Union, Kosovars are forced to obtain passports, or visas of countries in the region (in most cases they are forged), or cross the border of Kosovo illegally to the countries of European Union.

Cases of kidnapping of persons or children by delinquents are a dangerous act, which violates the safety of the citizens of Kosovo.

The use of premises for prostitution and the financing of income from prostitution is an illegal act, which increases the degree of risk for the development of trafficking in human beings.

Endangering the life of persons, accompanied by severe physical or psychological suffering, beatings, sexual intercourse with violence, etc. affects the concealment of trafficking in human beings in Kosovo.

\footnotetext{
${ }^{1}$ Council of Europe Convention against Human Beings, 03.05.2005 Brussels.

2 The Convention states that national authorities are responsible if they do not take measures to prevent trafficking in human beings, to protect victims and to effectively investigate cases of trafficking. Trafficking in human beings is a worldwide phenomenon, and as such knows no borders. The Convention is therefore valid and open to all countries in the world.

3 Psame source

4 Property owners who have a low level of education and as a result they do not have relevant documents to prove ownership in the state bodies of Kosovo.
} 
Social security focuses on freedom from fear and freedom from the dependence of human beings which is based on state policies. In the absence of freedom; for biological family regeneration, national identity, religious identity, class identity, free speech, private initiative, etc. the citizen's right to a democratic life is violated, which stifles initiatives for creative and quality life. Due to the lack of complete security in the country, the citizens whose freedom is violated, they look for other alternatives for a better quality of life, but who may fall prey of deceit for the traffickers.

So, the task of policymakers is to identify state policies, which regulate the functioning of the rule of law, increase the level of security and prevent trafficking in human beings.

\section{Social factors}

a) Family culture, or tradition of the population

The population of Kosovo was organized according to the patriarchal type of life until the end of the twentieth century - young women and girls had limited freedom in the family compared to men. Thus, they have cultivated the patriarchal mentality, while over time, especially after 1999 when Kosovo was placed under the protectorate of the UN Security Council, the respective institutions have been created which empower Kosovar women, integrating them in all spheres. of political, economic and social life.

The more women or women are emancipated, the more violence is reported against them by men.

Poverty, in particular, has become the most pronounced cause of violence against women and females in general. However, unwanted marriages have also become the cause of violence which continuously reproduces domestic violence (1. physical violence 2. psychological violence 3. sexual violence 4. economic violence, etc.).

Persistent domestic violence leads to frequent divorces, which are accompanied by social problems, in particular by trafficking.

Trafficking in women includes all girls and women who are recruited for prostitution and become a source of sexual violence.

The lack of perspective of young people forces them to face difficulties in employment, survival, realization of personal freedoms in the justice system in Kosovo.

b) Impact of countries in the region 
As a result of the global economy, organized crime, human rights violations are present in Kosovo as well. The influence of countries in the region in the development of trafficking in human beings in Kosovo stems from; a) Arrival of victims of trafficking from different countries of the region (trafficking of women from the countries of the region and their exploitation, trafficking of children who are used as beggars, shoplifters etc. b) from informal emigration, etc.

Kosovo has become a destination for many victims of trafficking in illegal forms, who are mainly from Albania and Eastern European countries.

c) Information, respectively social networks.

One of the causes of trafficking in human beings is the abuse of electronic means, respectively the use of social networks.

Recruiters take advantage of the victims' demand, taking advantage of their immaturity (adolescence), misery and state of mind, and so on.

The process of trafficking in human beings starts from the moment of contact, "socialization", the way of deception, building mutual trust, exploiting the victim, threatening not to recognize the family, maintaining his relations with the traffickers (with his exploiter). As a result of the circumstances created, their choice is imposed as a painful alternative (UN, 2008).

Thus, the state security bodies have the obligation to work towards crime prevention through social networks, respectively through various forms of information.

On the other hand, it is necessary to increase the capacities for raising the awareness of persons who are potential for trafficking, by educating, informing and qualitatively integrating them in the Kosovar society (in order to have a healthy, sustainable and free society.

Results of the analysis of trafficking in human beings as a consequence of the impact of economic development

One of the most worrying phenomena in Kosovar society is trafficking in human beings, known as modern slavery. Trafficking in human beings is organized by traffickers (as individual crime, organized apocalypse), who aim to profit from the victims (recruits). These organized groups recruit people with the greatest emotional sensitivity (victims of trafficking), who can be: a) people who have domestic violence, b) stigmatized people, c) people deceived for a better life, f) unemployed persons, g) students, h) persons with special talents, who aim to be realized in the most developed countries, i) persons forced for trafficking of their own organs ${ }^{1}$, etc.

\footnotetext{
1 Trafficking in human beings in Kosovo mainly includes the following types of exploitation of victims of trafficking: a) exploitation of victims for prostitution, b) exploitation for begging, c) coercion for forced marriage, d) coercion to perform hard labor , f) other forms of slavery, etc.
} 
Kosovo, as a country in transition, has made changes in the philosophy of the concept of economy, abandoning the concept of centralized economy, respectively the system of self-governing socialism and focusing on the free market economy in order to rebuild the new economic-political system.

With the change of the owner of the property, the relations of productive forces and relations in production has changed (employer-employee relations) as well as other changes;

a) the unemployment rate has increased, b) the poverty rate has increased, c) wealth has been concentrated in the hands of capital owners, d) social policies have changed (which are not balanced as the interests of employers and employees, because the collective contract signed by the partners of the three parties is not respected; Trade Unions - Government - Chambers of Commerce), e) the legal infrastructure is not completed, which as such is non-functional, etc.

Thus, macroeconomic indicators show that Kosovo's economy is permeated by the unstable economic situation, which leads to an unpromising prospect for the younger generations.

$\begin{array}{llllll}\text { Years } & \begin{array}{l}\text { Sexual } \\ \text { Abuse }\end{array} & \begin{array}{l}\text { Forcing in } \\ \text { hard work }\end{array} & \text { Slavery } & \begin{array}{l}\text { Begging and } \\ \text { forced } \\ \text { marriage }\end{array} & \begin{array}{l}\text { Total Nr of } \\ \text { victims }\end{array} \\ 2015 & 6 & 8 & 3 & 13 & 30 \\ 2016 & 8 & 11 & 2 & 15 & 36 \\ 2017 & 7 & 11 & 4 & 10 & 32 \\ 2018 & 4 & 5 & 2 & 4 & 15 \\ 2019 & 8 & 10 & 3 & 5 & 26 \\ 2020 & 5 & 5 & 2 & 5 & 17 \\ \text { Total } & 38 & 50 & 16 & 52 & 156\end{array}$

Fig. Nr.8. Data table of victims of trafficking in human beings for the period 2015 2020. (Source: Kosovo Police) 
Based on the table above, it can be seen that the trend of trafficking in human beings in Kosovo during the period 2015-2020 has a decrease in the number of victims. While in 2015 there were 30 victims, in 2020 there were 17 victims.Also from the table above it can be seen that, in total, for the period 2015-2020, 156 victims were trafficked in Kosovo, of which 38 victims were sexually abused, while 50 victims were exploited for forced labor, 16 victims were used as slaves and 52 victims were forced into marriage.

\section{Discussions and conclusions}

We live in a country in transition, with low economic development which embodies the concept of social problems: unemployment, poverty, migration, negative phenomena which are reflected in society.

So, as a result of this transition, Kosovo has been continuously aggravated by economic instability, political instability and social deregulation.

From the above parameters, it results that the level of quality welfare in Kosovo is low, therefore the gaps of the economic, political and social system, address individuals towards negative phenomena towards informality.

According to the Kosovo Police for the 5-year period 2016-2020, the number of identification of business facilities in which the activity of trafficking in human beings has taken place has been a total of forty (40). While the number of facilities closed by court decision due to the suspicion that trafficking in human beings took place in them was twelve (12) in total.

Also, we posses datas from the Center for the Protection of Victims and the Prevention of Trafficking in Human Beings. The number of victims of trafficking in human beings and potential victims who have been rehabilitated and returned to normal life (including the provision of medical, psychological, legal and material assistance), from 2016 to 2020 was a total of one hundred and thirty seven (137), beneficiaries (victims of trafficking and potential victims of trafficking) of which seventy-four (74) residential beneficiaries (staying 24 hours) referred by the Kosovo Police, AntiTrafficking Unit and Centers for Social Work, as and sixty-three (63) daily beneficiaries, children at risk of being trafficked, referred by the primary schools of the Municipality of Prishtina.

While the number of victims of trafficking in human beings reintegrated after rehabilitation, in order to successfully integrate into social life (in normal and free life, providing adequate access to educational services has been seventy-four (74) in total. Forty-six (46) beneficiaries have joined the reintegration program, benefiting from vocational training, permanent and secure housing opportunities and financial independence through the provision of various (self-employment) opportunities. 
Trafficking in human beings is an organized crime, which leaves consequences in many dimensions, so a greater institutional effort is needed to prevent, reintegrate victims, implement legal measures against defendants so that the consequences are smaller and the degree of recidivists to be smaller.

\section{Recommendations}

1. Improving employment policies, development policies, in order for economic growth to improve, to improve living standards and to move towards economic sustainability.

2. To reign political stability in order to exist a state with a higher degree of rule of law.

3. To function a social stability, an individual security in order to develop a creative and quality life not to violate the freedom of citizens.

4. Improving social policies (social scheme), alleviating poverty by creating better welfare so that citizens do not fall prey to other alternatives (the phenomenon of trafficking in human beings).

5. Awareness, higher sensibilisation of society through the media (social media surveillance), education, through religious actors to heve their impact for the damage that comes as a result of the process of trafficking in human beings.

6. Legislation needs to work and be implemented in order to reduce the recidivism rate.

7. Greater responsible institutional efforts are needed towards the prevention, protection, reintegration of victims of trafficking in human beings.

8. Closer co-operation is needed between the main actors, between policy makers, between the first responders, the judiciary, non-governmental organizations, in order to combat human trafficking from many dimensions.

\section{References}

[1] CFI. (n.d.). Neoclassical Economics - Overview, Assumptions, Key Concepts . Retrieved from www.corporatefinanceinstitute.com

[2] Government. (2016, January). National Strategy for Development 20162021. Retrieved from Plan for sustainable development: https://kryeministri.rksgov.net/repository/docs/Strategjia_Kombetare_per_Zhvillim_20162021_Shqip.pdf

[3] Government. (2017, March Pristina). National Program for the Implementation of the Stabilization and Association Agreement 2017-2021. Retrieved from https://mapl.rks-gov.net/wpcontent/uploads/2017/06/PKZMSA-20172021shq.pdf 
[4] Group, W. B. (2019). Western Ballkans Labour Market Trends 2019. wiiw, The Vienna Institute for International Economic Studies. Viena: World Bank Group. Retrieved from The Vienna Institute for International Economic Studies.

[5] Minister, O. P. (2016, January). National Development Strategy for 20162021. Retrieved from Plan for sustainable development: https://kryeministri.rks gov.net/repository/docs/Strategjia_Kombetare_per_Zhvillim_20162021_Shqip.pdf

[6] President. (2020). National Strategy for European Integration, Kosovo 2020, A Participatory Approach. Retrieved from National Council for European Integration: https://presidentksgov.net/repository/docs/Strategjia_Kombetare_per_Integrimin_Evropian_ Kosovo_2020_ALB.pdf

[7] Ritzer, G. \&. (2008). Sociological Theory, p 84-87. Tirana: Shepia Botuese UFO Press. P48-55.

[8] Statistics, K. A. (n.d.). Kosovo Agency of Statistics. Retrieved from https://ask.rks-gov.net/

[9] UN. (2008, February). Human Trafficking a Crime that Shames us all. An Introduction to Human Trafficking: Vulnerability, Impact and Action. United Nations Office on Drugs and Crimes. Retrieved from Office on Drugs and Crime: https://www.unodc.org/unodc/en/about-unodc/speeches/200802-13.html 